\title{
Analisis Kegagalan Komponen Driver Plate dalam Cooler Clinker Pada Unit Tuban I PT. Semen Indonesia Tbk.
}

\author{
Mohamad Miftah Fadlika Makmur, Alvian Toto Wibisono, dan Lukman Noerochim \\ Departemen Teknik Material, Fakultas Teknologi Industri, Institut Teknologi Sepuluh Nopember (ITS) \\ e-mail: lukman@mat-eng.its.ac.id
}

\begin{abstract}
Abstrak-Mesin pendingin terak (clinker cooler) berfungsi sebagai pendingin terak (clinker) yang keluar dari mesin pemanas (kiln). Drive plate berfungsi untuk membawa terak dari kiln dengan menggerakan crossbar dalam proses pendinginan terak. Beberapa pengujian dilakukan untuk mendukung hasil analisis. Uji komposisi didapatkan material driver plate berkesesuaian komposisinya dengan ASTM A709. Pengamatan makroskopik menunjukkan adanya deformasi, terlihat dari perubahan geometri. Pengamatan mikroskopik menunjukkan struktur mikro daerah yang terdeformasi mengalami strain hardening. Analisis dengan bantuan software menunjukan besar total deformation dan equivalent stress. Besar total deformasi sebesar $4.4 \mathrm{~mm}$. Dan uji kekerasan menunjukkan adanya peningkatan nilai kekerasan di daerah dekat dengan kegagalan, dari 348.2 \pm 9 BHN menjadi 370.6 \pm 17 BHN. Faktor yang menyebabkan kegagalan adalah pemilihan material dan deformasi.
\end{abstract}

Kata Kunci-Drive Plate, Clinker Cooler, Deformasi.

\section{PENDAHULUAN}

$\mathrm{P}$ ESERO Terbatas Semen Indonesia merupakan produsen semen terbesar di Indonesia. Keberhasilan pembangunan pabrik Tuban IV dan Tonasa V, serta akuisisi perusahaan semen Vietnam Thang Long Cement Company pada akhir tahun 2013, maka pada awal tahun 2013 perseroan memiliki kapasitas terpasang sebesar 30 ton/tahun dan telah menjadi perusahaan semen terbesar di Asia Tenggara berdasarkan kapasitas terpasang. Proses pembuatan semen PT. Semen Indonesia unit Tuban 1 secara garis besar melalui proses dengan dimulai dari pengambilan bahan baku, proses pembuatan klinker, proses penggilingan semen dan packing semen. Dalam proses produksi semen ini, terdapat banyak equipment yang digunakan dan salah satunya adalah clinker cooler. (Ibrahim,2004)

Semen sendiri terdiri atas bahan baku utama dan bahan baku tambahan jika ditinjau dari segi fungsinya. Material yang termasuk bahan baku utama adalah batu kapur $\left(\mathrm{CaCO}_{3}\right)$, clay (tanah liat), pasir silika $\left(\mathrm{SiO}_{2}\right)$, iron sand $\left(\mathrm{Fe}_{2} \mathrm{O}_{3}\right)$. Serta bahan baku tambahan dari semen adalah trass, gypsum dan dolomit. Proses produksi semen yang pertama yaitu penambangan bahan baku untuk pembuatan semen terutama batu kapur $\left(\mathrm{CaCO}_{3}\right)$ dan clay (tanah liat) menggunakan alat-alat berat kemudian dikirim ke pabrik, yang kedua, bahan-bahan yang telah ditambang kemudian diteliti di laboratorium kemudian dicampur dengan proporsi yang tepat dan kemudian dilanjutkan ke proses penggilingan awal (raw mill) untuk memperkecil dimensi material. Proses selanjutnya adalah bahan kemudian dipanaskan di preheater, dilanjutkan di dalam kiln sehingga bereaksi membentuk kristal klinker. Kiln ini menggunakan bahan dasar pembakaran batu bara yang sebelumnya diproses di coal mill yang berjenis vertical roller mill, agar ukuran batu bara ini dapat digunakan pada kiln. Kristal klinker ini kemudian didinginkan di cooler dengan bantuan angin. Panas dari proses pendinginan ini di alirkan lagi ke preheater untuk menghemat energi. Klinker ini kemudian dihaluskan lagi dalam tabung yang berputar yang bersisi bola-bola baja yaitu pada ball mill sehingga menjadi serbuk semen yang halus. Klinker yang telah halus ini disimpan dalam silo. Dari silo ini semen di packing dan dijual ke konsumen [1].

Mesin pendingin terak (clinker cooler) berfungsi sebagai pendingin terak (clinker) yang keluar dari mesin pemanas (kiln). Clinker yang keluar dari kiln akan dihantarkan menuju mesin penggiling (hammer crusher) melalui papan silang (crossbar) yang pada prosesnya di gerakan oleh batang berjalan (Driver Plate) yang berjajar diatas bagian cooler. Maka dari itu, dibutuhkan sifat kekerasan dan ketangguhan yang tinggi untuk komponen Driver Plate mengingat kondisi terak (Clinker) yang memiliki temperature tinggi akibat proses pemanasan di kiln. Pada Januari 2017, Driver Plate pada clinker cooler mengalami fenomena perubahan bentuk (Deformation). Komponen Driver Plate mengalami kegagalan berupa deformasi yang diakibatkan oleh beban yang terlalu besar dan kerja yang terus menerus, sehingga mengakibatkan equipment Clinker cooler berhenti berjalan di karenakan komponen lain yang lepas. Material standar untuk driveplate adalah HARDOX 500 atau HARDOX 600.Dalam penelitian ini dilakukan variasi temperatur dan media pendingin proses hardening untuk memperoleh fasa martensit sehingga mendapatkan kekerasan sesuai standar.

Berdasarkan jenis kegagalan yang terjadi, maka hipotesa awal yang mungkin terjadi berupa dislokasi yang disebabkan oleh beban kerja yang terlalu berat dan juga kondisi temperature yang terlalu tinggi sehingga menyebabkan suatu pergeseran atau pegerakan atom-atom di dalam sistem kristal logam akibat tegangan mekanik yang dapat menciptakan deformasi plastis atau perubahan sturktur material secara permanen [2]. Maka dari itu, dilakukanlah analisis terhadap kegagalan ini untuk membuktikan hipotesa awal tersebut, agar kegagalan ini tidak terjadi lagi. Dengan melakukan beberapa pengujian seperti uji komposisi, uji mikroskopi, uji makroskopi dan perhitungan dari studi lapangan serta studi literature mengenai deformasi pada benda padat. 


\section{METODE PENELITIAN}

\section{A. Review Dokumen Perusahaan}

Review dokumen perusahaan dilakukan untuk mendapatkan data data perusahaan yang berkaitan dengan Driver Plate sebagai pendukung hasil penelitian, berikut data yang harus diambil yaitu desain driver plate, data operasi, spesifikasi material, maintenance record.

\section{B. Preparasi Spesimen}

Tahap Persiapan ini diperlukan sebelum melakukan pengujian untuk menentukan penyebab kegagalan Driver Plate pada PT Semen Indonesia. Persiapan ini berupa proses cutting dan sectioning. Proses pemotongan dilakukan pada bagian ujung driver plate yang terindikasi adanya perubahan geometri dan jauh dari deformasi. Spesimen yang terindikasi adanya perubahan geometri serta bagian yang jauh dari deformasi akan diuji sebagai perbandingan antara material yang baru dengan material yang sudah gagal. Proses pemotongan dilakukan dengan jenis pemotongan wire cut.

\section{Uji Komposisi}

Pengujian komposisi kimia adalah untuk mengetahui komposisi kimia yang terdapat pada komponen yang mengalami kegagalan. Pada identifikasi komposisi kimia menggunakan alat Optical Emission Spectroscopy (OES) di Laboratorium Uji Bahan Politeknik Perkapalan Negeri Surabaya (PPNS) untuk mengetahui komposisi yang ada pada driver plate.

\section{D.Pengamatan Makroskopik}

Pengamatan makro dilakukan untuk mengetahui bentuk, tampilan dan lokasi komponen yang mengalami kegagalan secara makro. Pengamatan makro dilakukan menggunakan kamera digital. Adapun perlakuan terhadap sampel material adalah dengan melakukan pengambilan fotografi driver plate yang sedang di ukur geometrinya dengan menggunakan jangka sorong dengan kamera digital untuk mendapatkan informasi bentuk dari kegagalan secara makro.

\section{E. Analisis Mikrostruktur}

Spesimen dilihat dengan berbagai macam perbesaran untuk melihat bentuk, ukuran, fasa yang terbentuk dengan menggunakan mikroskop optik. Pada penelitian ini dilakukan analisis hasil dari mikrostuktur dari driver plate yang gagal [3].

\section{F. Pengujian Kekerasan}

Pengujian kekerasan dilakukan untuk mengetahui distribusi kekerasan dengan melakukan indentasi di beberapa titik pada sampel material. Pengujian ini dilakukan dengan metode Brinell dimana dalam pengujiannya memakai indentor bola baja, pembebanan sebesar $187.5 \mathrm{kgf}$ dan waktu indentasi selama 15 detik [4]. Pengujian ini mneggunakan Universal Hardness Tester HBRV 187.5A di Laboratorium Metalurgi, Jurusan Teknik Material dan Metalurgi, ITS.

\section{HASIL DAN PEMBAHASAN}

\section{A. Record Driver Plate di Clinker Cooler Unit 1 Tuban}

Pada bulan Januari 2017 PT. Semen Indonesia Tuban Plant 1 sedang melaksanakan maintenance rutin. Kemudian di Cooler Clinker 1 ditemukan sebuah kegagalan dari Driver Plate yang merupakan komponen dari mesin Cooler Clinker
1. Driver plate tersebut beroperasi selama 10 bulan. Driver plate dirancang dapat beroperasi dengan usia pakai 1 tahun (12 bulan). Driver plate ini dirancang untuk menggunakan material HARDOX 500. Gambar 1 menunjukkan desain dari driver plate. Tabel 1 menunjukkan data-data driver plate dan cooler clinker.

Berikut ini data-data dari crossbar mencakup spesifikasi crossbar pada clinker cooler.

Tabel 1.

Data Operasi crossbar di clinker cooler Tuban 3 PT. Semen Indonesia

\begin{tabular}{ll}
\hline \hline Lebar Plate & $2.00 \mathrm{~mm}$ \\
\hline Tebal Plate & $95 \mathrm{~mm}$ \\
\hline Panjang Plate & $600 \mathrm{~mm}$ \\
\hline Massa Clinker & $1440 \mathrm{Kg} / \mathrm{Jam}$ \\
\hline Temperatur Kerja & $652^{\circ} \mathrm{C}$ \\
\hline \hline
\end{tabular}

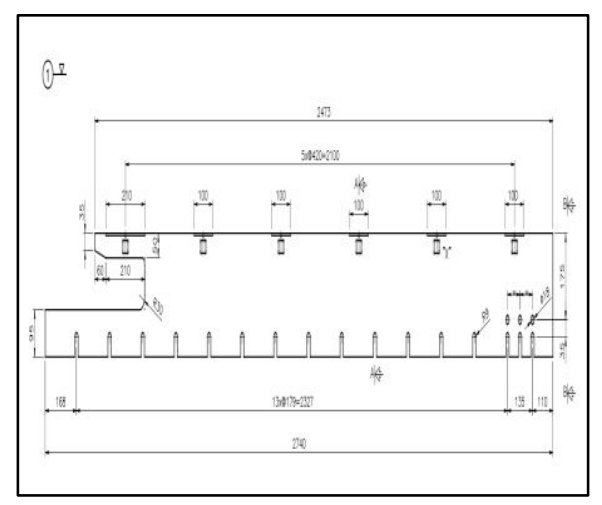

Gambar 1. Desain crossbar di PT. Semen Indonesia.

Tabel 2.

Sifat Mekanik HARDOX 500

\begin{tabular}{ll}
\hline \hline Kekerasan (BHN) & Kekuatan Yield (MPa) \\
\hline $470-530$ & 1400 \\
\hline \hline
\end{tabular}

\section{B. Pengujian Optical Emission Spectroscopy}

Pengujian ini dilakukan untuk mengamati komposisi unsur pada spesimen driver plate dengan menggunakan OES (Optical Emission Spectroscopy). Tabel 3 menunjukkan hasil pengujian yang dibandingkan dengan komposisi unsur HARDOX 500 yang dimana merupakan material yang seharusnya di gunakan oleh cooler clinker.

Tabel 3.

Perbandingan material uji dan material HARDOX 500

\begin{tabular}{|c|c|c|c|c|c|c|c|c|}
\hline Unsur & $\mathrm{C}$ & $\mathrm{Si}$ & $\mathrm{Mn}$ & $\mathrm{Ni}$ & $P$ & Mo & $\mathrm{Cr}$ & $\mathrm{Fe}$ \\
\hline $\begin{array}{c}\text { Material } \\
\text { Uji }\end{array}$ & 0.175 & 0.5 & 1.3 & 0.45 & 0.017 & 0.265 & 0.37 & Balance \\
\hline $\begin{array}{c}{ }^{1} \text { HARDOX } \\
\quad 500\end{array}$ & 0.27 & 0.5 & 1.6 & 0.25 & 0.025 & 0.25 & 1.2 & Balance \\
\hline
\end{tabular}

Berdasarkan Tabel 3 di atas, material HARDOX 500 yang seharusnya di gunakan pada komponen driver plate memiliki komposisi yang berbeda dengan material driver plate yang mengalami kegagalan [5]. Perbedaan tersebut terlihat jelas pada komposisi Carbon (C), Mangan (Mn), dan juga Chromium $(\mathrm{Cr})$. Pada unsur Carbon specimen driver plate yang lebih rendah dibandingkan HARDOX 500 dengan perbedaan mencapai 0.23 dapat menyebabkan kekuatan dan kekerasan dari material drive plate lebih rendah, dan perbedaan karbon ini juga menyebabkan berbedanya ekspansi thermal dari material tersebut. Semakin tinggi unsur karbon pada material maka ekspansi thermal 
akan semakin menurun. Material dengan komposisi seperti HARDOX 500 yaitu AISI 1030 memiliki nilai ekspansi thermal sebesar $11.7 \mathrm{l} / \mathrm{m}^{\circ} \mathrm{C}$ sedangkan material dengan komposisi seperti material driver plate yaitu AISI 1006 memiliki nilai ekspansi thermal sebesar 12.6 \ m/m $/ \mathrm{m}^{\circ} \mathrm{C}[6]$, yang berarti semakin tinggi unsur karbon pada material maka semakin sulit untuk melakukan pemuaian akibat pengaruh temperature. Sama halnya dengan unsur Mangan dan Chromium dari material driver plate yang lebih rendah dibandingkan HARDOX 500 dengan perbedaan secara berturut-turut 0.32 dan 0.83 dapat menyebabkan hardenability yang dimiliki oleh specimen driver plate lebih rendah. Dimana semakin tinggi unsur paduannya maka hardenability dari material semakin meningkat. Hardenability yang tinggi menandakan unsur paduannya yang tinggi, karena hardenability merupakan kemampuan paduan untuk menghasilkan martensit yang tinggi di seluruh volume specimen [7].

Tabel 4.

Perbandingan hasil uji komposisi unsur dari spesimen driver plate dengan komposisi unsur ASTM A709

\begin{tabular}{ccccccccc}
\hline \hline Unsur & $\mathrm{C}$ & $\mathrm{Si}$ & $\mathrm{Mn}$ & $\mathrm{Ni}$ & $\mathrm{P}$ & $\mathrm{Mo}$ & $\mathrm{Cr}$ & $\mathrm{Fe}$ \\
\hline $\begin{array}{c}\text { Material } \\
\text { Uji }\end{array}$ & 0.175 & 0.5 & 1.3 & 0.45 & 0.017 & 0.265 & 0.37 & Balance \\
\hline $\begin{array}{c}\text { ASTM } \\
\text { A709 }\end{array}$ & 0.2 & 0.4 & 1.5 & 0.45 & 0.035 & 0.15 & 0.35 & Balance \\
\hline \hline
\end{tabular}

\section{Pengamatan Makroskopik}

Gambar 2 menunjukkan hasil visual dari permukaan driver plate yang mengalami kegagalan. Terlihat kegagalan driver plate berupa deformasi atau perubahan bentuk dan ukuran. Perubahan bentuk dan ukuran dari driver plate ditunjukkan dengan gambar 2 dimana terdapat perbedaan ketinggian dari daerah yang terdeformasi dan tidak terdeformasi. Deformasi juga ditunjukan dengan perubahan dimensi ukuran di daerah kegagalan seperti yang ditunjukkan pada Gambar 3. Lebar pelat mula mula sebesar $95.0 \mathrm{~mm}$ kemudian mengalami perubahan ukuran menjadi $97.9 \mathrm{~mm}$.

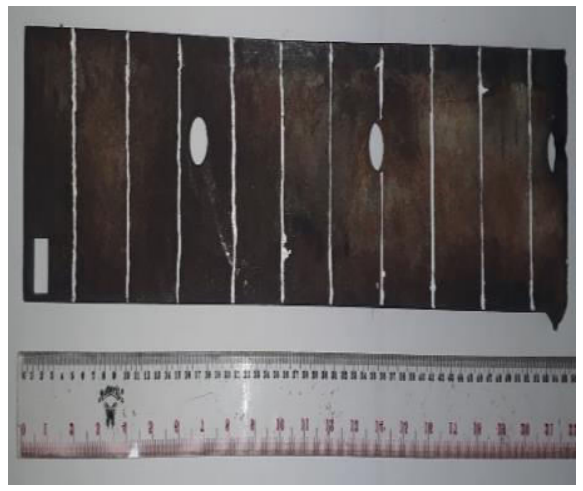

Gambar 2. Pengamatan makroskopik permukaan spesimen Driver plate

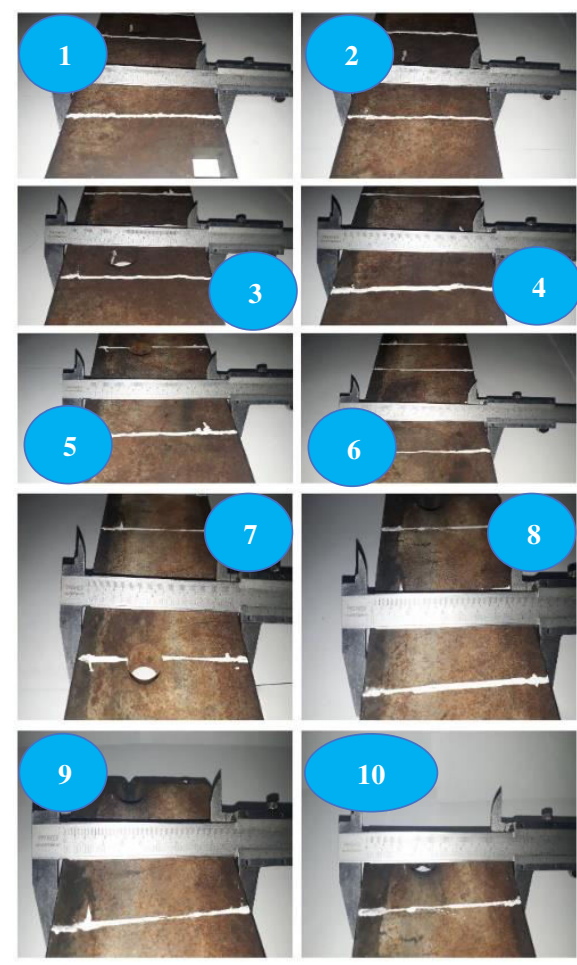

Gambar 3. Pengukuran lebar komponen Driver plate.

Tabel 5.

Lebar Driver Plate

\begin{tabular}{cccc}
\hline \hline Titik Uji & $\begin{array}{c}\text { Lebar awal } \\
(\mathrm{mm})\end{array}$ & $\begin{array}{c}\text { Lebar akhir } \\
(\mathrm{mm})\end{array}$ & Selisih lebar (mm) \\
\hline 1 & 95 & 96.7 & 1.7 \\
2 & 95 & 96.8 & 1.8 \\
3 & 95 & 97 & 2 \\
4 & 95 & 97.1 & 2.1 \\
5 & 95 & 97.2 & 2.2 \\
6 & 95 & 97.2 & 2.2 \\
7 & 95 & 97.5 & 2.5 \\
8 & 95 & 97.7 & 2.7 \\
9 & 95 & 97.9 & 2.9 \\
10 & 95 & 97.9 & 2.9 \\
\hline \hline
\end{tabular}

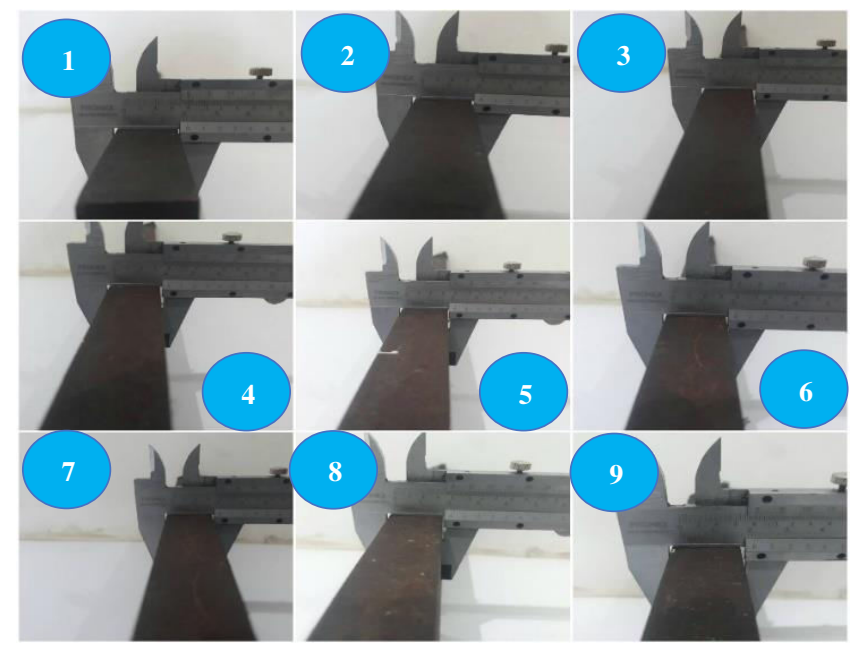

Gambar 4. Pengukuran tebal komponen Driver plate.

Tabel 6.

Tebal Driver plate

\begin{tabular}{cccc}
\hline \hline Titik Uji & $\begin{array}{c}\text { Tebal awal } \\
(\mathrm{mm})\end{array}$ & Tebal akhir $(\mathrm{mm})$ & Selisih tebal $(\mathrm{mm})$ \\
\hline 1 & 2 & 1.97 & 0.03 \\
\hline \hline
\end{tabular}




\begin{tabular}{cccc}
\hline \hline 2 & 2 & 1.96 & 0.04 \\
3 & 2 & 1.96 & 0.04 \\
4 & 2 & 1.96 & 0.04 \\
5 & 2 & 1.955 & 0.045 \\
6 & 2 & 1.955 & 0.045 \\
7 & 2 & 1.95 & 0.05 \\
8 & 2 & 1.95 & 0.05 \\
9 & 2 & 1.94 & 0.06 \\
10 & 2 & 1.94 & 0.06 \\
\hline \hline
\end{tabular}

Dari gambar 3 dan tabel 5 terlihat bahwa material driver plate mengalami perubahan geometri berupa perubahan lebar. Dari titik uji 1 sampai titik uji 10, lebar dari driver plate semakin besar melebih dari lebar awalnya. Dapat dilihat bahwa selisih lebar paling besar ada pada titik uji 10 sebesar $2.9 \mathrm{~mm}$. Terlihat juga pada gambar 4 dan table 6 bahwa material driver plate mengalami perubahan geometri pada tebalnya. Dari titik uji 1 sampai 10, tebal dari driver plate semakin besar melebihi dari awalnya. Terlihat bahwa selisih tebal paling besar ada pada titik 10 sebesar $0.06 \mathrm{~mm}$. Hal ini diakibatkan oleh design dari driver plate yang memiliki satu fixed support sehingga bagian yang semakin jauh dari fixed support memiliki ruang lebih untuk memuai dan mengalami perubahan geometri yang diakibatkan oleh beban kerja dan kondisi temperatur kerja mencapai $652^{\circ} \mathrm{C}$. Perubahan geometri yang ditunjukan pada table 5 dan table 6 diatas berbanding terbalik dengan fenomena muai dari baja pada umumnya. Baja akan memuai jika mengalami kenaikan temperatur dan akan kembali menyusut jika kembali pada kondisi temperatur semula. Material yang mengalami penyusutan memiliki kemampuan untuk kembali ke kondisi geometri yang sama dalam kondisi termal semula, tetapi laju penyusutan ini dipengaruhi oleh waktu dan media pendinginannya [8]. Material driver plate menerima beban termal sebesar $652^{\circ} \mathrm{C}$, mengalami pemuaian sehingga mempengaruhi komponen lain yang bekerja di dalam cooler clinker dan ketika driver plate mengalami kegagalan maka cooler clinker berhenti bekerja. Pada kasus ini material driver plate mengalami pendinginan yang lambat sebelum akhirnya diangkat untuk di ganti. Pendinginan yang lambat menyebabkan material driver plate mengalami penyusutan yang kecil sehingga geometri dari material driver plate tidak kembali seperti semula.

\section{Hasil Pengamatan Struktur Mikro (Metalografi)}

Gambar 5 menunjukan hasil struktur mikro pada driver plate. Pada gambar 5 (a) merupakan foto struktur mikro dari daerah yang jauh dari deformasi. Pada gambar terlihat beberapa fasa, terdapat acicular ferrite, lath martensit, upper bainite, dan polygonal ferrite. Terbentuknya struktur mikro tersebut akibat pendinginan yang lambat. Pada gambar 5 (b) terlihat beberapa fasa, terdapat polygonal ferrite, lath martensit dan upper bainit. Dari dua gambar di atas dapat diketahui bahwa daerah yang berada di dekat deformasi memiliki sifat mekanik yang lebih keras dibandingkan dengan daerah yang jauh dari deformasi.

Ini menunjukkan terjadinya mekanisme yang sesuai dengan pengerasan logam. Strain hardening merupakan suatu fenomena yang terjadi pada material driver plate ini. Fenomena ini biasanya terjadi jika adanya deformasi permanen yang di akibatkan slip pada material tersebut [9]. Strain hardening terjadi karena adanya pemanjangan struktur mikro dari material, terlihat dari gambar 5 (b) bahwa struktur lath martensit, upper bainit dan juga polygonal ferrite mengalami pemanjangan batas butir.
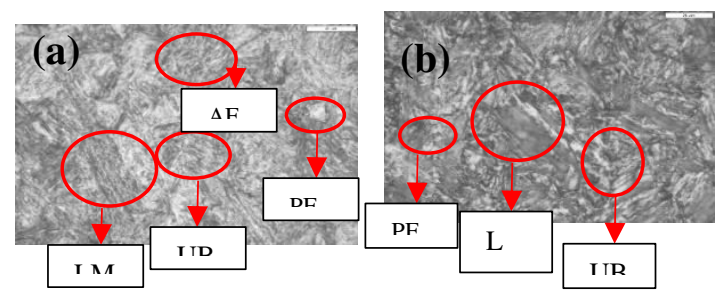

Gambar 5. Foto struktur mikro material driver plate (a) daerah jauh dari deformasi, dan (b) dekat dari deformasi pada perbesaran 1000X.

\section{E. Hasil Pengujian Kekerasan Brinnel Material}

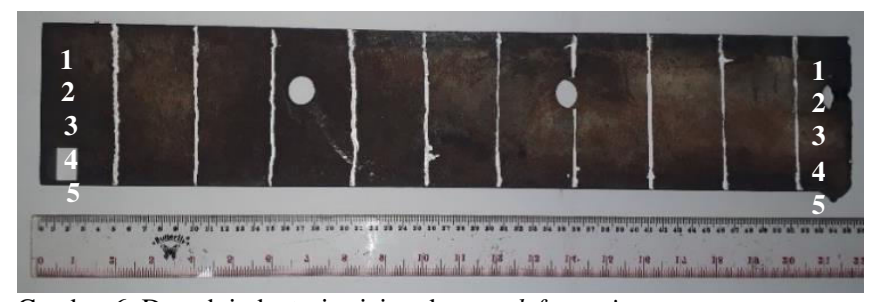

Gambar 6. Daerah indentasi sejajar dengan deformation.

Pengujian kekerasan dilakukan untuk mengetahui distribusi nilai kekerasan pada driver plate yang mengalami kegagalan. Metode yang digunakan adalah Vickers Hardness Test dengan beban $187.5 \mathrm{kgf}$ berdasarkan ASTM E-10. Pengujian ini menggunakan indentasi sebanyak 10 titik. 5 titik pada bagian yang tidak terdeformasi dan 5 titik pada bagian yang terdeformasi. Indentasi tersebut tersebar merata pada daerah yang dekat dan jauh dari deformasi. Pembagian daerah indentasi dapat dilihat pada Gambar 6.

Dari table 7 menunjukan sifat kekerasan material driver plate pada daerah yang jauh dari deformasi dan dekat dengan deformasi. Pada daerah yang jauh dari deformasi memiliki distribusi nilai kekerasan yang stabil dengan rata rata sebesar $348.2 \pm 9$ dan pada daerah yang dekat dengan deformasi memiliki nilai kekerasan dengan rata - rata sebesar $370.6 \pm 17$ serta memiliki distribusi nilai kekerasan yang cendenrung tidak merata.

Tabel 7.

Data Hasil Pengujian Kekerasan Dekat dari crack

\begin{tabular}{|c|c|c|c|}
\hline $\begin{array}{c}\text { Area } \\
\text { Indentasi } \\
\text { (Jauh } \\
\text { deformasi) }\end{array}$ & $\begin{array}{c}\text { Nilai Kekerasan } \\
(\mathrm{BHN})\end{array}$ & $\begin{array}{c}\text { Araea } \\
\text { Indentasi } \\
\text { (Dekat } \\
\text { deformasi) }\end{array}$ & $\begin{array}{c}\text { Nilai } \\
\text { Kekerasan } \\
(\mathrm{BHN})\end{array}$ \\
\hline 1 & 355 & 1 & 389 \\
\hline 2 & 353 & 2 & 363 \\
\hline 3 & 355 & 3 & 389 \\
\hline 4 & 334 & 4 & 357 \\
\hline 5 & 344 & 5 & 355 \\
\hline Rata - rata & $348.2 \pm 9$ & Rata - rata & $370.6 \pm 17$ \\
\hline
\end{tabular}

\section{F. Analisis dengan Bantuan Sofrware}

Pengujian ini dilakukan untuk memperlihatkan pola deformasi yang terjadi pada komponen [10] driver plate dengan batasan kondisi temperature sebesar $600^{\circ} \mathrm{C}$, gaya yang bekerja sebesar $14400 \mathrm{~N}$ dan juga fixed support yang berada pada bagian kiri komponen driver plate. Hasil dari analisis menggunakan software ini di tunjukan pada gambar 6 yang memperlihatkan analisis untuk total stress dan gambar 7 yang memperlihatkan analisis untuk total deformation seperti berikut. 


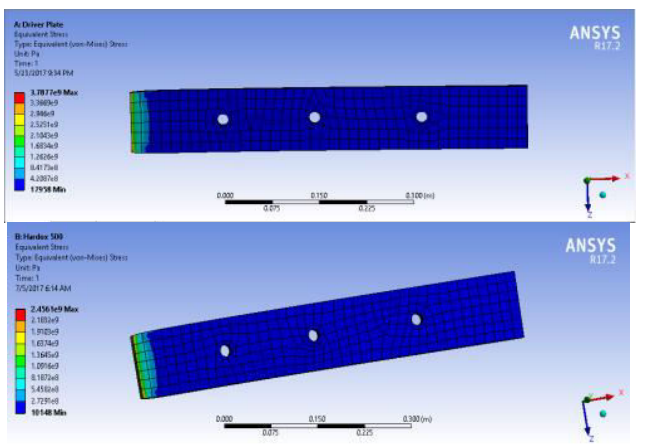

Gambar 6. Hasil analisis untuk total stress (a) Driver Plate (b) HARDOX 500

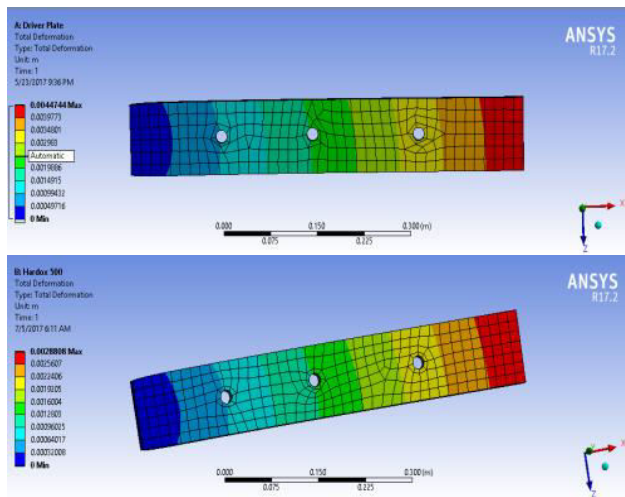

Gambar 7. Hasil analisis untuk total deformation (a) Driver Plate (b) HARDOX 500.

\section{KESIMPULAN}

Berdasarkan serangkaian percobaan dan analisis yang telah dilakukan, terdapat beberapa kesimpulan mengenai kegagalan dari driver plate pada cooler clinker antara lain sebagai berikut:

1. Faktor yang menyebabkan terjadinya kegagalan komponen driver plate pada cooler clinker yaitu kesalahan pemilihan material yang seharusnya merupakan HARDOX 500, serta deformasi.

2. Mekanisme kegagalan komponen driver plate pada cooler clinker diawali oleh beban clinker yang terdistribusi merata di atas driver plate melebihi ketahanan dari material tersebut. Deformasi plastis di tandai dengan nilai kekerasan yang meningkat akibat adanya strain hardening dan perubahan geometri dari driver plate.

3. Melakukan pemilihan material (material selection) yang lebih baik sesuai dengan kemampuan material dalam menahan beban kerja selama beroperasi.

4. Menggunakan material yang sesuai dengan standar yaitu HARDOX 500.

5. Dengan desain yang sama, memilih material baja tahan karat dengan sifat ketahanan aus dan muai panjang yang lebih kecil.

\section{DAFTAR PUSTAKA}

[1] Semen Padang, "Pengenalann Menuju Pabrik Semen," 2011.

[2] K. Anwar, "Analisis Perpindahan Panas Grate Cooler Industri Semen. Palu," Palu, 2011.

[3] ASM International, "ASM Handbook Vol.9 Metallographic and Microstructure. Material Park.," Ohio, 2002.

[4] G. E. Dieter, Metalurgi Mekanik. Jakarta: Erlangga, 1987.

[5] SSAB Technology, Data Sheet HARDOX 500 Sheet. Sweden: Greencoat, 2016.

[6] ASM International, "ASM Handbook Vol.12 Deformation," 2002.

[7] S. H. Avner, Introduction To Physical Metallurgy. Singapore: Mc Graw Hill, 1974.

[8] S. C. Donald and R. W. Varney, Physical Metallurgy for Engineers. California: Litton Educational Publishing Inc, 1962.

[9] W. Callister, Material Science and Engineering an Introduction. New York: John Wiley \& Sons Inc, 2007.

[10] D. Neil and J. Eaton, "Investigation of 3D flow and Heat Transfer in Solid-fuel Grate Combustion: Measure to Reduce Temperature Degradation." 